\title{
A Review of the Developed New Model Biodiesels and Their Effects on Engine Combustion and Emissions
}

\author{
Shenghua Liu ${ }^{1} * \mathbb{0}$, Wei Chen ${ }^{1}$, Zengqiang Zhu ${ }^{1}$, Sa Jiang ${ }^{1}$, Tongtong Ren ${ }^{1}$ and Hejun Guo ${ }^{2}$ \\ 1 School of Energy and Power Engineering, Xi'an Jiaotong University, Xi'an 710049, China; \\ davidchen@difite.com (W.C.); zhuzengqiang2013@stu.xjtu.edu.cn (Z.Z.); 13399102273@163.com (S.J.); \\ tongtong_ren@163.com (T.R.) \\ 2 Xi'an Research Institute of High Technology, 603 PO Box, Xi'an 710025, China; cn.ghj_2002@163.com \\ * Correspondence: shenghua@mail.xjtu.edu.cn; Tel.: +86-139-9186-4433
}

Received: 13 October 2018; Accepted: 15 November 2018; Published: 19 November 2018

\begin{abstract}
Biodiesel is regarded to be a renewable, $\mathrm{CO}_{2}$ neutral and thus sustainable biological alternative diesel fuel. With attention to the reduction of petroleum import, PM 2.5 aerosol particles and the greenhouse effect gas $\mathrm{CO}_{2}$, biodiesel has drawn great research interests and efforts in the past decade in China. Generally, biodiesel refers to fatty acid methyl ether (FAME) which has a proved effect in reducing diesel emission, particularly PM. However, FAME has a limited cetane number and oxygen content, to study the effects of elevated cetane number and oxygen content on fuel properties, engine combustion and emissions, ethylene glycol monomethyl ether is used to produce a series of new models of biodiesels by transesterification method. The feedstocks are rapeseed oil, soybean oil, peanut oil, palm oil and cottonseed oil. Ether group alcohols used in this study include ethylene glycol monomethyl ether, ethylene glycol monoethyl ether, ethylene glycol monopropyl ether, propylene glycol monomethyl ether, diethylene glycol monomethyl ether, triethylene glycol monomethyl ether. The molecular structure was proved by FT-IR and NMR analyses. Fuel properties were measured based on the corresponding standards. The developed new model biodiesels have cetane number $(\mathrm{CN})$ over 70 and oxygen content over $17 \%$ by mass, which are higher than FAME ( $50 \mathrm{CN}$ and $11 \%$ oxygen). They have the same level of lower heating value as FAME, but have a higher density, which helps to compensate the decrease of engine power. Meanwhile, the engine tests were carried out to investigate the effects of ether ester group on engine combustion and emissions. The test results show that FAME reduced smoke $30 \%$ to $50 \%$, while the new model biodiesel fuels reduced engine smoke as high as $80 \%$ and have the potential to decrease engine $\mathrm{HC}, \mathrm{CO}$ and $\mathrm{NO}_{\mathrm{x}}$ emissions $50 \%$ or more.
\end{abstract}

Keywords: biodiesel; ethylene glycol monomethyl ether; engine; combustion; emission

\section{Introduction}

Diesel engines are robust, powerful and efficient enough, therefore they are widely used in trucks, off-road vehicles, farming machineries, electricity generation plants and so on. More and more diesel engines are put into use which consumed a great quantity of diesel fuel. For example, as showed in Figure 1, in 2017 in China, about 180 million tons of diesel fuel had been consumed [1]. As it is known, diesel engine heterogeneous combustion occurred within its cylinders results in higher $\mathrm{NO}_{\mathrm{x}}$ and $\mathrm{PM}$ emissions [2,3]. The statistic data of the regulated pollutants of $\mathrm{CO}, \mathrm{HC}, \mathrm{NO}_{\mathrm{x}}$ and $\mathrm{PM}$ of vehicles are showed in Figure 2, which is cited from China Vehicle Environmental Management Annual Report (2018) [4]. It can be seen that diesel vehicles contribute almost 100\% PM and $68.3 \% \mathrm{NO}_{\mathrm{x}}$ emissions of 
vehicles. To give a direct impression about the share rate, for example in Beijing, the vehicles contribute about $45 \%$ of total air PM 2.5 pollution.

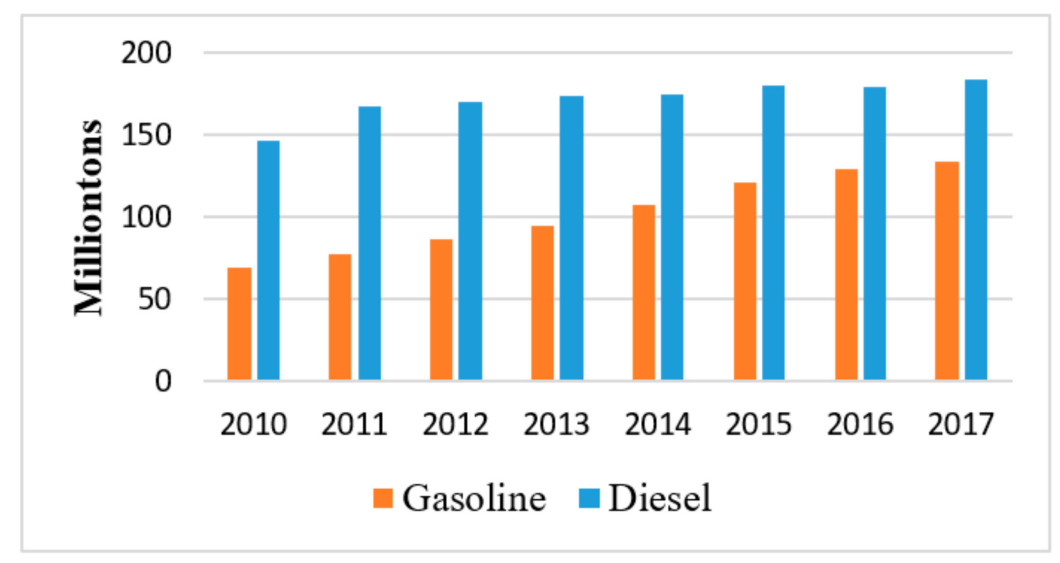

Figure 1. The statistic gasoline and diesel consumption from 2010 to 2017 [1].

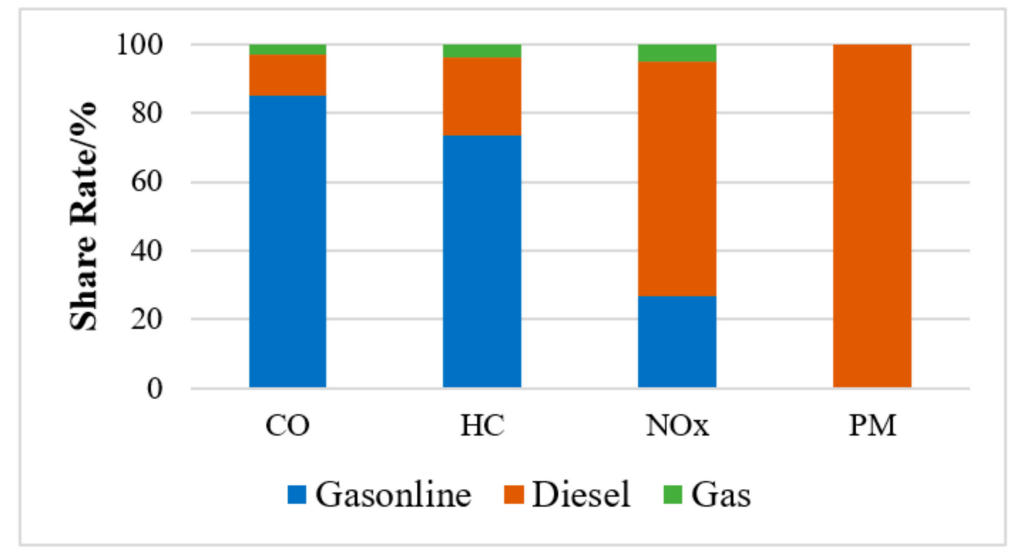

Figure 2. Vehicle emission share rate according to fuels [4].

Biodiesel was thought to be $\mathrm{CO}_{2}$ neutral and sustainable. With attention to the reduction of PM 2.5 and the greenhouse effect gas $\mathrm{CO}_{2}$, it drew great research interests and efforts in the past decade and got a rising market world widely. Therefore, China is so confident to carry out biodiesel application programs to control the emission from diesel vehicles following the world trend and to cease the pressure of petroleum importation as well.

The biodiesel market entered a booming period since 2006 and reached a key milestone in 2011 to follow the United Nations Framework Convention on Climate Change in the world, which is showed in Figure 3. Figure 3 also shows a similar development trend of biodiesel in the US, EU and China [5-7]. In the US, 2016 market was a record high of 2.8 billion gallons according to EPA figures showed in Figure 4. In Europe Union, driven by the Renewable Energy Directive, biodiesel should be $10 \%$ till 2020. The produced and imported quantity of biodiesel in 2017 was 14 million tons according to Figure 5 . It was about $10 \%$ of biodiesel in transport diesel approximately. In China, promoted by China the 12th and 13th Five-Year Plan for Renewable Energy Development [8,9]. Biodiesel Industry Development Policy [10], it can be seen from Figure 6 that the development of the domestic biodiesel market has truly entered a booming period after 2013. In 2017, China biodiesel production is about 1.1 million tons. Even if 5\% biodiesel is added to the petrodiesel, the market will be at least 9 million tons accordingly. There is a vast market space for the development of biodiesel. So, it is important to carry out studies of biodiesel for its application in engines, especially in China. 


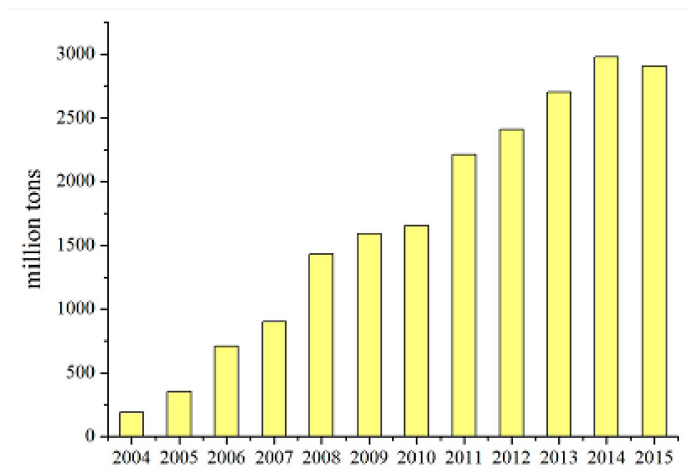

(a)

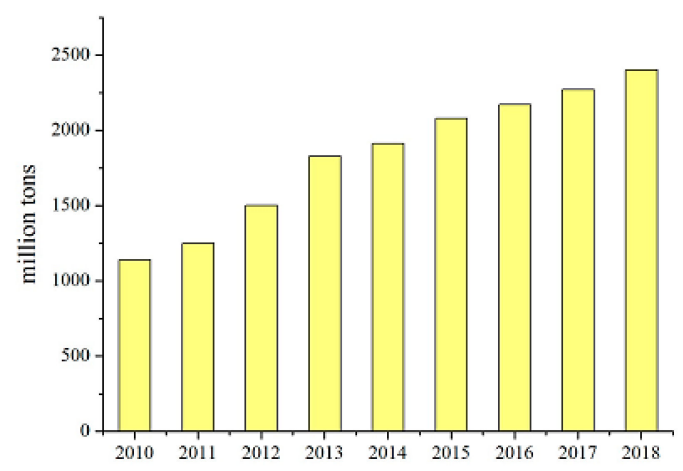

(c)

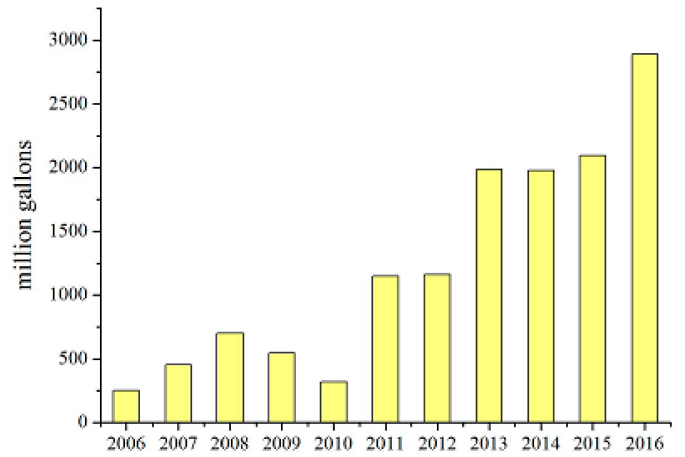

(b)

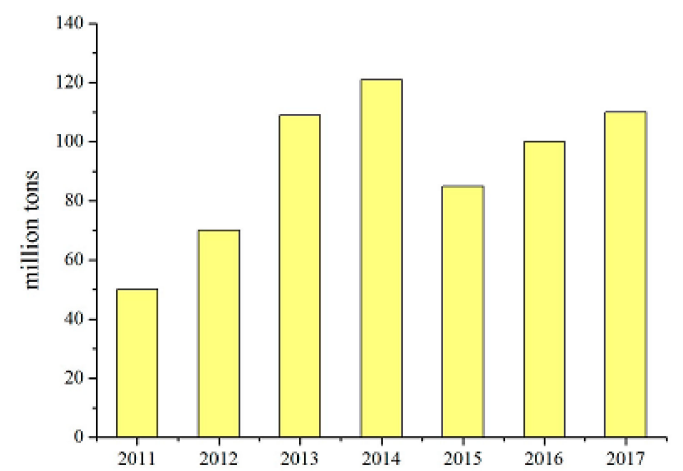

(d)

Figure 3. (a) Worldwide biodiesel productions; (b) US biodiesel market; (c) Biodiesel consumption in EU; (d) China biodiesel production from 2013 to 2017 [5-7].

A number of studies have examined the emission impacts of biodiesel [5,11-17]. The commonly accepted results are showed in Figure 4 from a US DOE report [18]. It can be seen that more biodiesel means better reduction of $\mathrm{CO}, \mathrm{HC}$ and PM of the engine, however, biodiesel was mostly used with petrodiesel in a lower proportion due to the fuel properties of density, viscosity, oxidation stability, et al., and their complex effects on the fuel spray atomization, evaporation and combustion. In practice, most countries allow $5 \%$ or less than $10 \%$ blending with petrodiesel. For example in the quality of European diesel fuels, it is specified by the EN 590 standard, FAME content is 7\% as regulated by Directive 2009/30/EC [19].

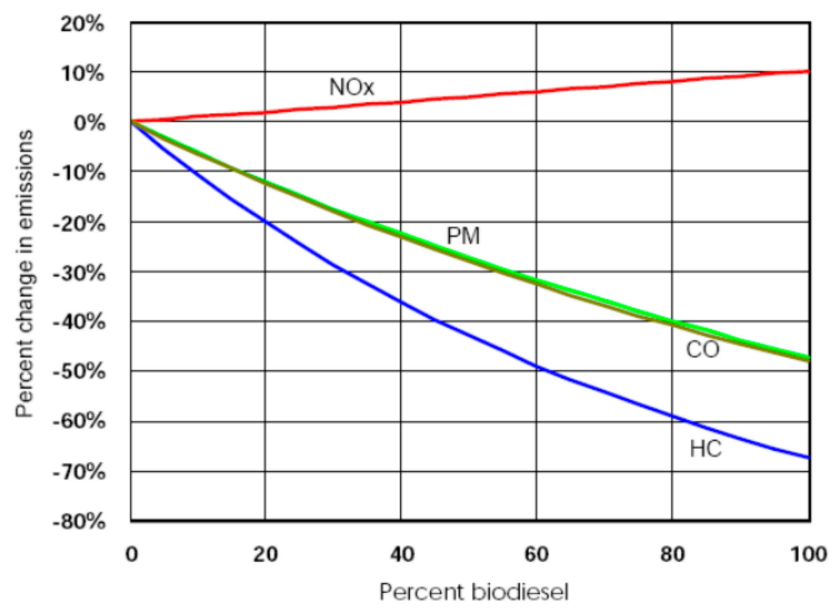

Figure 4. Trends in percentage change of pollutant emissions with biodiesel content [18].

There are several advantages and disadvantages for the application of biodiesel as engine fuel $[5,11-17,20]$. They are summarized as below. 
1. It is renewable, safe and biodegradable. Biodiesel can be made from vegetable oils, animal fats, or recycled restaurant greases (waste cooking oils). Both the original materials and the product of biodiesel are safe and can be degraded naturally.

2. It can reduce greenhouse gas emissions. A life cycle analysis of biodiesel showed that overall $\mathrm{CO}_{2}$ emissions were reduced by $78 \%$ compared with petrodiesel fuel, which will contribute to domestic and international targets of greenhouse gas reductions.

3. It has a similar cetane number as compared to petrodiesel, so it can be used alone, or blended with petrodiesel in any proportions.

4. It is an oxygenated fuel without sulfur content, which can promote engine combustion and reduce emissions of $\mathrm{HC}, \mathrm{CO}$ and $\mathrm{PM}$, which helps to reduce the environmental pollution.

5. It has better lubricity, and unsaturated esters possess a slight advantage. So, there is no need to reconsider the lubricity of the engine fuel injection system when biodiesel is applied.

6. It is a mix of mono-alkyl esters of long chain fatty acids. It has a higher cloud and pour point (CP and PP) temperatures, density, and kinematic viscosity as well as the acid value compared to diesel, affecting the utility of the fuel, especially in cold conditions.

7. The calorific value of biodiesel is about $37.27 \mathrm{MJ} / \mathrm{kg}$. There is $9 \%$ lower than regular petrodiesel. Fuel injection systems measure fuel by volume, and thus, engine output power may be affected under high ratio or pure application conditions.

8. It comprises of saturated and unsaturated esters. Saturated fatty esters are very stable, while unsaturated esters are likely to react with oxygen, therefore reduce oxidation stability.

9. And finally, because of its renewable feature, the use of biodiesel can reduce its dependence on foreign fossil fuels. Sustainable energy supply is necessary for the economic development of a country like China, whose petroleum depends much on import.

For the application of biodiesel, cetane number is the most concerned parameter. The $\mathrm{CN}$ of most conventional biodiesel are around 50 , which meet the requirement of $\mathrm{CI}$ engine, especially under low fraction blending application [21-26]. However, the effects of reducing exhaust emissions are not so significant. There were studies showed that the improvement of $\mathrm{CN}$ may results in reduction of biodiesel engine emissions. Higher $\mathrm{CN}$ leads to lower $\mathrm{NO}_{\mathrm{x}}$, higher oxygen content decreases $\mathrm{CO}, \mathrm{HC}$, PM emissions [27-30]. So, instead of methanol, substances containing more oxygen should be adopted to increase $\mathrm{CN}$ and oxygen content for biodiesel.

Conventional biodiesel is prepared through transesterification of vegetable oils or fatty oils with methanol. There are only two oxygen atoms existing in biodiesel molecule, hence the oxygen content in conventional biodiesel is not high. Although the conventional biodiesel has high cetane number (about 50) as petrodiesel, it has not evident competition superiority [21-24,26,27,31,32]. The developed new model biodiesel is synthesized through transesterification reaction of vegetable oils and ethylene glycol ether derivatives. The ether group introduced into biodiesel molecule promotes its octane number and oxygen content to 70 and $17 \%$ approximately, which finally proves to have a better performance than conventional biodiesel in reducing engine emissions, especially smoke can be reduced $80 \%$ approximately.

This review is to summarize our researches about the new model biodiesels. Transesterification processes were simply described and proved to be the same as FAME. The synthesized biodiesel itself, its fuel properties, engine test equipment and engine performance were reviewed respectively, which proves our research activity is interesting and progressive.

\section{New Model Biodiesels and Their Fuel Properties}

\subsection{New Model Biodiesels}

For transesterification, the interest was focused on ethylene glycol monomethyl ether. Ethylene glycol can be made by methanol, as well as ethylene glycol monomethyl ether. They are cheap, small 
molecular with high oxygen content, high cetane number. In this case, the produced biodiesel may have a reasonable price to compete with petrodiesel.

The new model of biodiesel is synthesized just like FAME, ethylene glycol monomethyl ether first reacts with catalyst, see sodium (Na) in Equation (1). Sodium ethylene glycol monomethyl ether is formed, and then it is mixed with vegetable oils like rapeseed oil, palm oil, et al. Transesterification reaction occurs as described in Equation (2) with an optimized reactants fraction. The chemical process completes under moderate condition like $60{ }^{\circ} \mathrm{C}$, water bath at atmosphere pressure in laboratory. The mixture should be treated by phase separation, hydrochloric acid (HCI) washing, filter, dry, and finally, new model biodiesel is obtained. The procedures can be simply showed in Figure 5.
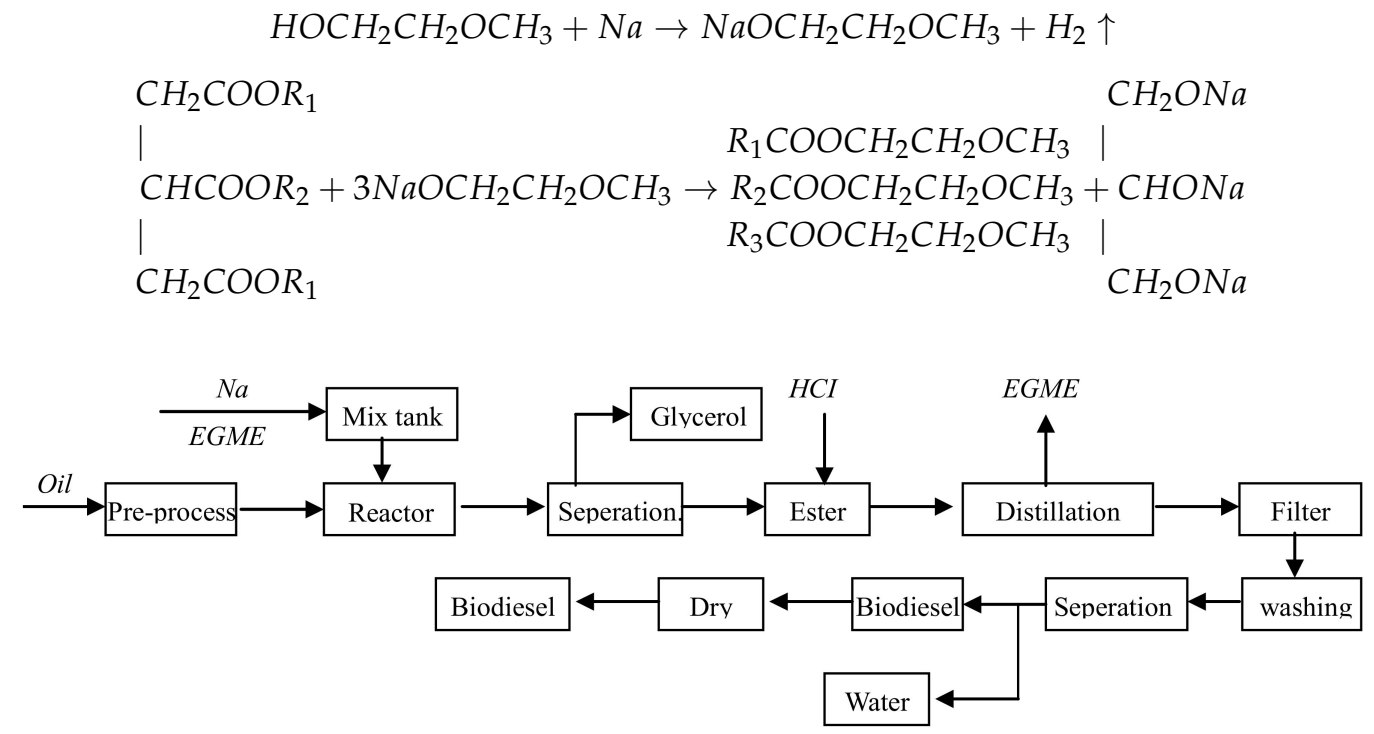

Figure 5. Biodiesel producing processes.

The chemical structure of the synthesized biodiesel can be identified through Fourier transform infrared (FT-IR) spectrum and proton nuclear magnetic resonance $\left({ }^{1} \mathrm{H}\right.$ NMR) spectrum analyses [33,34]. Different groups, such as methyl, methylene, carbonyl, $\mathrm{C}-\mathrm{O}-\mathrm{C}$ and $\mathrm{C}=\mathrm{C}$, etc., possess distinct vibrational frequency and generate different characteristic infrared absorption spectrum. Furthermore, protons attributed to different group under different chemical environment in the molecule also have quite different characteristic chemical shifts, splitting multiplicity and coupling constants. Based on these obtained characteristic data, the chemical structure of the new model biodiesel can be deduced. In addition, analyses by gel permeation chromatography (GPC) can acquire the data of average molecular weight and molecular weight distribution of the new model biodiesels as well as its originating vegetable oil. The GPC data can be used to make a comparison between the biodiesel and the vegetable oil to further confirm the chemical structure of the new model biodiesel.

\subsection{Biodiesel Fuel Properties}

Biodiesel is produced by different feedstocks, such as soybean oil in US, rapeseed oil in EU, palm oil in Southeast Asia countries and so on, according to their planting production [22]. China is known to feed one forth global population by too less farm land, so biodiesel is thought to be made by nonedible oil, waste cooking grease oil. The most developed oils were from jatropha curcas, pistacia chinensis, et al., which can be planted in the mountain areas such as Guizhou and Hainan Provinces [21]. Different stocks have different length, structure and content of mono-alkyls. Some 11 common feedstocks of biodiesel are showed in Table 1 . The length of most chain is 16 or18, some contain 1 or 2 or 3 unsaturated olefinic bonds. The number of olefinic bond and their containing percentage are used to calculate Degree of Unsaturation (DU). The available researches proved that there is a negative correlation between the DU and CN of biodiesel. Biodiesels are used in CI engines, 
their CNs are very important parameters. It was correlated in Equation (3). According to their Degree of Unsaturation, their Cetane Number can be estimated [24], and the results are listed in the Table 2, as well.

$$
\mathrm{CN}=65.0958-0.1209 \times \mathrm{DU}
$$

The oxygen content is generally measured by element analysis method. Available data are given in Table A1 in Appendix A [21-24,26,27,31].

It can be seen that the cetane number and oxygen content of FAME are around 50 and $11 \%$, which are less affected by oil stocks. To improve these fuel properties, new types of biodiesel were developed. Ethylene glycol monomethyl ether was mostly used to react with different vegetable oils to synthesize different biodiesels, so that their effects of ether group and fatty acids on engine combustion and emissions can be compared. Meanwhile ethylene glycol ethyl ether and propyl ether types biodiesels and diethylene glycol and triethylene glycol monomethyl ether types of biodiesels were developed to understand their effects. Table 1 lists some of new types of biodiesels and their fuel properties our group developed in recent years [32-50].

Table 1. New models of biodiesels and some of their fuel properties [32-50].

\begin{tabular}{|c|c|c|c|c|c|c|}
\hline Oil & Alcohol & Product & Density & LHV & OC & $\mathrm{CN}$ \\
\hline 0\# diesel & / & 0\# diesel & 860 & 42.5 & 0 & 50 \\
\hline $\begin{array}{l}\text { Rapeseed } \\
\text { Cottonseed }\end{array}$ & methanol & $\mathrm{RCOOCH}_{3}$ & $\begin{array}{l}884 \\
886\end{array}$ & $\begin{array}{c}1 \\
37.5\end{array}$ & $\begin{array}{c}10.9 \\
10\end{array}$ & $\begin{array}{l}51 \\
52\end{array}$ \\
\hline $\begin{array}{l}\text { Rapeseed } \\
\text { Soybean } \\
\text { Peanut } \\
\text { Cottonseed }\end{array}$ & ethylene glycol methyl ether & $\mathrm{RCOOCH}_{2} \mathrm{CH}_{2} \mathrm{OCH}_{3}$ & $\begin{array}{c}910 \\
907.2 \\
939.1 \\
901.5\end{array}$ & $\begin{array}{l}38.7 \\
38.5 \\
37.0 \\
38.5\end{array}$ & $\begin{array}{c}/ \\
/ \\
/ \\
14.3\end{array}$ & $\begin{array}{c}1 \\
66 \\
/ \\
70.1\end{array}$ \\
\hline $\begin{array}{l}\text { Palm } \\
\text { Soybean }\end{array}$ & ethylene glycol ethyl ether & $\mathrm{RCOOCH}_{2} \mathrm{CH}_{2} \mathrm{OC}_{2} \mathrm{H}_{5}$ & $\begin{array}{l}893.4 \\
902.7\end{array}$ & $\begin{array}{l}36.2 \\
38.6\end{array}$ & / & 80.4 \\
\hline Palm & ethylene glycol n-propyl ether & $\mathrm{RCOOCH}_{2} \mathrm{CH}_{2} \mathrm{OC}_{3} \mathrm{H}_{7}$ & / & 37.3 & 16.35 & 72.3 \\
\hline Palm & propylene glycol methyl ether & $\mathrm{RCOOCH}\left(\mathrm{CH}_{3}\right) \mathrm{CH}_{2} \mathrm{OCH}_{3}$ & 889.2 & / & I & I \\
\hline Cottonseed & $\begin{array}{l}\text { diethylene glycol methyl ether } \\
\text { triethylene glycol methyl ether }\end{array}$ & $\begin{array}{l}\mathrm{RCO}\left(\mathrm{OCH}_{2} \mathrm{CH}_{2}\right)_{2} \mathrm{OCH}_{3} \\
\mathrm{RCO}\left(\mathrm{OCH}_{2} \mathrm{CH}_{2}\right)_{3} \mathrm{OCH}_{3}\end{array}$ & $\begin{array}{l}912.0 \\
935.5\end{array}$ & $\begin{array}{l}37.0 \\
35.8\end{array}$ & $\begin{array}{l}16.88 \\
18.90\end{array}$ & $\begin{array}{l}76.9 \\
80.9\end{array}$ \\
\hline Standard & & & ASTM & ASTM & ASTM & ASTM \\
\hline
\end{tabular}

The new types of biodiesels have a CN around 70, oxygen content about $17 \%$, which are higher than FAME.

\section{Test Engine and Parameter Measurement}

A single cylinder diesel engine was adopted in these studies. It is water cooled and natural aspired. The main technical specifications are listed in Table 2. A twin cylinder, water cooled and natural aspired diesel engine with the same emission level was applied, too. Its specifications are listed in Table 2.

Table 2. Single and Twine cylinder diesel engine parameters.

\begin{tabular}{|c|c|c|}
\hline Engine Type & $2102 \mathrm{QB}$ & TY1100 \\
\hline Bore $\times$ Stroke $(\mathrm{mm})$ & $102 \times 115$ & $100 \times 115$ \\
\hline Displacement $\left(\mathrm{cm}^{3}\right)$ & 1880 & 903 \\
\hline Chamber shape & $\omega$ & $\omega$ \\
\hline Compression ratio & $17.5: 1$ & 18:1 \\
\hline Rated power $(\mathrm{kW}) @$ speed $\left(\mathrm{r} \cdot \mathrm{min}^{-1}\right)$ & $23.5 / 2300$ & $11 / 2300$ \\
\hline Injector type & ZCK154S432 & ZCK154S432 \\
\hline Nozzle hole number-diameter (mm) & $4 \times \Phi 0.3$ & $4 \times \Phi 0.3$ \\
\hline Delivery timing (deg. BTDC) & 25 & 25 \\
\hline Injection pressure (MPa) & 19.0 & 19.0 \\
\hline
\end{tabular}


The biodiesel used in the tests were laboratory produced. They ran the test diesel engines purely or mixed with China 0\# petrodiesel of that time in several different ratios. Some of the related fuel properties are listed in Table 1. The blended fuel properties can be referred in the related literatures. During the tests, the engine was kept under warmed up condition at water temperature of $80^{\circ} \mathrm{C}$ and lubricant oil temperature of $60^{\circ} \mathrm{C}$. The change of fuels followed a standard schedual in case of mixing with the former fuel.

The test conditions were mainly compared at $1400 \mathrm{r} \cdot \mathrm{min}^{-1}$ and $2200 \mathrm{r} \cdot \mathrm{min}^{-1}$, the max torque speed and the related speed conditions, respectively. The applied equipment in the engine tests were Kistler pressure sensors and DL750 Data Acquisition System, AVL DiGas and DiSmoke, et al. Engine combustion and emissions data were focused here and compared with the results of the pure petrodiesel operation. The experimental setup for engine combustion performance and emissions measurement is shown in Figure 6. An electrical eddy-current dynamometer was applied to determine the engine torque and brake mean effective pressure (BMEP) can be calculated. An AVL DiSmoke4000 opacimeter was used to record smoke number expressed in extinction coefficient. A five-gas analyzer of type AVL DiGas4000 light was utilized to examine $\mathrm{NO}_{\mathrm{x}}, \mathrm{CO}$ and $\mathrm{HC}$ emissions on-line. A Kistler pressure sensor, a charge amplifier and the DL750 Data Acquisition System were adopted to measure and record the cylinder pressure, then the heat release rate can be computed according to the First Law of energy conservation and the relationship between crank angle degrees and cylinder volume.

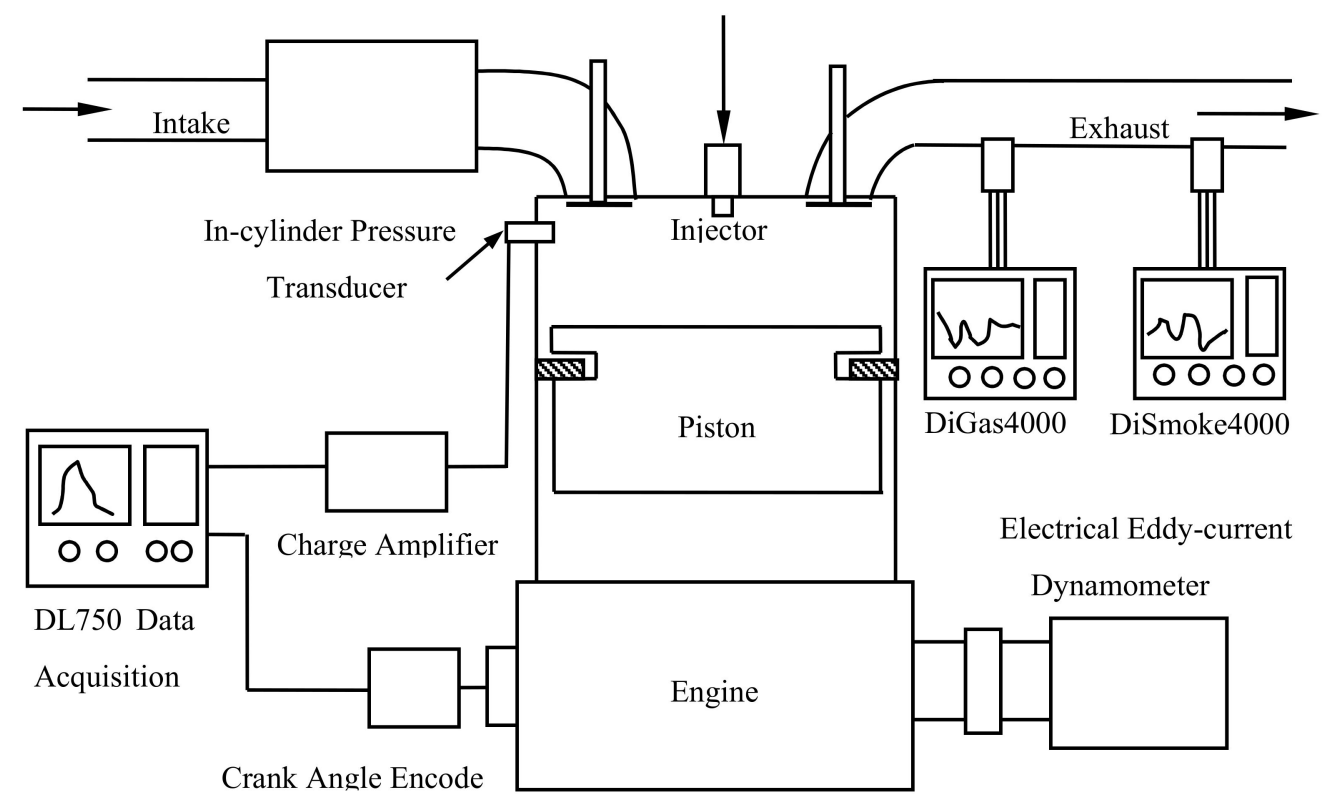

Figure 6. Experimental setup for engine tests.

\section{Engine Test Results}

Several kinds of biodiesel were developed in the past decade research activities. Except FAME, ethylene glycol monomethyl ether based biodiesels were focused. The effects on engine performance are digested and compared below. To know the full results, please refer to the corresponding references.

\subsection{FAME}

To compare with ethylene glycol monomethyl ether types of biodiesel, cottonseed oil methyl ester was prepared and used to study the combustion and exhaust emissions characteristics by 2102QB diesel engine.

When the engine fueled with this cottonseed oil FAME purely, its brake thermal efficiency improved to be $32.2 \%$ and $33.6 \%$ at the conditions of $70 \mathrm{~N} \cdot \mathrm{m}, 1400 \mathrm{r} \cdot \mathrm{min}^{-1}$ and $2200 \mathrm{r} \cdot \mathrm{min}^{-1}$, which are $29.6 \%$ and $30.0 \%$ for the petrodiesel operation, respectively. 
Under $1400 \mathrm{r} \cdot \mathrm{min}^{-1}$ constant speed operating conditions, the exhaust smoke reduced by $30.0-47.4 \%$; $\mathrm{CO}$ emissions reduced by $20.0-33.3 \%$ at $1400 \mathrm{r} \cdot \mathrm{min}^{-1}$; $\mathrm{HC}$ emissions decreased by 18.2-36.4\%; and $\mathrm{NO}_{\mathrm{x}}$ emissions decreased by $3.2-16.6 \%$, respectively.

Under $2200 \mathrm{r} \cdot \mathrm{min}^{-1}$ constant speed operating conditions, the exhaust smoke reduced by $26.8-45.5 \%$; CO emissions reduced by $33.3-50.0 \%$; HC emissions decreased by $11.1-20.0 \%$ and $\mathrm{NO}_{\mathrm{x}}$ emissions decreased by $13.1-24.2 \%$, respectively.

\subsection{Ethylene Glycol Monomethyl Ether Based Biodiesel}

There were 5 vegetable oils used to react with ethylene glycol monomethyl ether to produce new model biodiesels. They are rapeseed oil, soybean oil, peanut oil, palm oil and cottonseed oil. The produced biodiesel can be named as Ethylene Glycol Methyl Ether X-oil Monoester. They have the same formula as $\mathrm{RCOOCH}_{2} \mathrm{CH}_{2} \mathrm{OCH}_{3}$, where the " $\mathrm{R}$ " means different chain alkyl, which are provided in Table 1 (some). Their fuel properties can be checked in Table 3.

1. Ethylene Glycol Methyl Ether Rapeseed Oil Monoester [33,34].

The test engine was TY1100. Under the pure biodiesel operating conditions, the effects of biodiesel are as the following.

- Effect on Combustion

The combustion analyzed heat release rate shows that the ignition delay becomes $1.1 \mathrm{deg}$. CAshorter. Both the maximum heat release rate and peak cylinder pressure increase. The brake thermal efficiency was improved.

- Effects on emissions

Under full load operating conditions, smoke reduces $43.5-78.2 \%$, the reduction of $\mathrm{CO}$ is $8.7-50 \%$ and $\mathrm{HC}$ is $11.4-61.5 \%$, while $\mathrm{NO}_{\mathrm{x}}$ a little increases.

2. Ethylene Glycol Methyl Ether Soyate Oil Monoester [38,39].

The test engine was TY1100. The tests were conducted mainly at $2300 \mathrm{r} \cdot \mathrm{min}^{-1}$ operating conditions. The engine ran on pure biodiesel of EGMMES and 50\% biodiesel blended with petrodiesel by volume. The effects of biodiesel are as the following.

- Effects on energy consumption

For pure biodiesel operating conditions, the consumption increases by $16.9 \%$ while the energy consumption decreases by $7.9 \%$, and for biodiesel and petrodiesel mixture operating conditions, the consumption increases by $1.4 \%$, while the energy consumption decreases by $3.2 \%$, respectively.

- Effects on emissions

For pure biodiesel operating conditions, smoke decreased from $54.7 \%$ to $85.7 \%$, CO emission reduced up to $79.1 \%$ for the pure and $69.8 \%$ for its mixture operation. HC emission decreased by $61.6 \%$. For biodiesel and petrodiesel $50 \%$ to $50 \%$ mixture operating conditions, smoke decreased from $46.5 \%$ to $83.3 \%$, CO emission reduced up to $69.8 \%$, HC emission decreased by $59.6 \%$. Both fuels do not change $\mathrm{NO}_{x}$ emission significantly.

3. Ethylene Glycol Methyl Ether Peanut Oil Monoester [32].

The test engine was TY 1100. The test fuels were petrodiesel, peanut oil monoester biodiesel and their mixture at a proportion of 1:1 by volume. Most tests conducted under $1400 \mathrm{r} \cdot \mathrm{min}^{-1}$ and $2000 \mathrm{r} \cdot \mathrm{min}^{-1}$. The results were as the following. 


\section{- Effect on Combustion}

The peanut oil monoester has high cetane number, leading to a little earlier auto-ignition than diesel. An improved engine thermal efficiency was observed when the engine fueled with the biofuel due to certain amount of oxygen contained in the new biodiesel. The peak cylinder pressure, pressure rise rate and the calculated heat release rate have no noticeable change.

- $\quad$ Effects on emissions

The exhaust smoke decreased by $25.0 \%$ to $75.0 \%, \mathrm{CO}$ and $\mathrm{HC}$ emissions were lowered by the maximum of $50-70 \%$ and $\mathrm{NO}_{\mathrm{x}}$ emission remained in the same level.

4. Ethylene Glycol Methyl Ether Palm Oil Monoester [40,41].

Smoke decreased by $69.0 \%$ to $89.3 \%$. $\mathrm{NO}_{\mathrm{x}}$ decreased about $25 \%$ at high speed conditions while increased $15 \%$ at low speed high load conditions. HC and CO emissions increased much (maybe mismarked, they should be decreased.)

5. Ethylene Glycol Methyl Ether Cottonseed Oil Monoester [42].

EGMECOM has a comparative high cetane number and oxygen content, which are the prime factors that determine its $\mathrm{NO}_{\mathrm{x}}$ and smoke emissions, respectively.

EGMECOM, the combustion timing of engine is advanced, ignition delay is shortened, and the combustion is improved.

Compared to diesel fuel, a maximal reduction of the smoke, $\mathrm{NO}_{x}, \mathrm{CO}$, and $\mathrm{HC}$ are $50.0 \%, 50.0 \%$, $20.0 \%$, and $55.6 \%$, respectively.

For convenient review, the test conditions and maximal reduction rate of emissions when using different biodiesel is summarized in Table 3. New model biodiesels are more significant than FAME in reducing smoke, $\mathrm{HC}$ and $\mathrm{CO}$ because of its higher $\mathrm{CN}$ and oxygen content. However new model biodiesels have a little influence in reducing $\mathrm{NO}_{\mathrm{x}}$ except EGMEPOM (Palm) and EGMECOM. The different effects on engine emissions should be studied further.

Table 3. Effect of biodiesel on the reduction of engine emissions [32-34,38-42].

\begin{tabular}{|c|c|c|c|c|c|c|}
\hline Fuel Type & Engine & Operation Condition & Smoke & HC & $\mathrm{CO}$ & $\mathrm{NO}_{\mathrm{x}}$ \\
\hline \multirow{2}{*}{ FAME } & \multirow{2}{*}{ 2102QB } & $1400 \mathrm{r} \cdot \min ^{-1}$ & $47.4 \%$ & $36.4 \%$ & $62.5 \%$ & $16.2 \%$ \\
\hline & & $2200 \mathrm{r} \cdot \min ^{-1}$ & $45.5 \%$ & $20.0 \%$ & $50.0 \%$ & $24.2 \%$ \\
\hline EGMEROM & TY110 & $2200 \mathrm{r} \cdot \min ^{-1}$ & $78.2 \%$ & $61.5 \%$ & $50.0 \%$ & Increase slightly \\
\hline EGMESOM & TY110 & $2200 \mathrm{r} \cdot \min ^{-1}$ & $74.6 \%$ & $61.6 \%$ & $79.1 \%$ & changeless \\
\hline \multirow{2}{*}{ EGMEPOM (Peanut) } & \multirow{2}{*}{ TY110 } & $1400 \mathrm{r} \cdot \min ^{-1}$ & $65.2 \%$ & $53.8 \%$ & $50.0 \%$ & changeless \\
\hline & & $2000 \mathrm{r} \cdot \min ^{-1}$ & $75.0 \%$ & $69.2 \%$ & $50.0 \%$ & changeless \\
\hline \multirow{2}{*}{ EGMEPOM (Palm) } & \multirow{2}{*}{ 2102QB } & $1400 \mathrm{r} \cdot \min ^{-1}$ & $58.3 \%$ & $66.7 \%$ & $60.0 \%$ & changeless \\
\hline & & $2000 \mathrm{r} \cdot \mathrm{min}^{-1}$ & $55.6 \%$ & $66.7 \%$ & $54.5 \%$ & $32.2 \%$ \\
\hline \multirow{2}{*}{ EGMECOM } & \multirow{2}{*}{ 2102QB } & $1400 \mathrm{r} \cdot \min ^{-1}$ & $50.0 \%$ & $55.6 \%$ & A little & $39.3 \%$ \\
\hline & & $2000 \mathrm{r} \cdot \mathrm{min}^{-1}$ & $45.5 \%$ & $55.6 \%$ & A little & $39.3 \%$ \\
\hline
\end{tabular}

\subsection{Other Models of New Biodiesels}

To study the effects of different biodiesel ether groups on engine combustion and emissions, different ether groups were selected and transesterified to biofatty acids, therefore, several kinds of biodiesels were prepared. Here listed are Ethylene Glycol Monoethyl Ether Soyate and Palm Oil Monoester, Ethylene Glycol propyl Ether Palm Oil Monoester, propylene glycol methyl ether palm oil monoester, diethylene glycol ethyl ether and triethylene glycol ethyl ether cottonseed oil Monoester were synthesized respectively. Their effects on engine combustion and emissions were digested below. 
1. Ethylene glycol ethyl ether Soyate oil monoester

Compared with petrodiesel operation, when ran on pure biodiesel or their mixture, the engine power output remained the same level, while fuel consumption increased to some extent. This was thought to be unit heat energy remained due to the same product of decrease of LHV and increase of density.

When pure biodiesel operating, engine smoke reduced by $59.8-83.3 \%$, CO reduction rate was 47.7-76.7\% and HC decreased by $48.9-64.7 \%$, while $\mathrm{NO}_{\mathrm{x}}$ increased little. When $50 \%$ blending operation, engine exhaust smoke reduced $37.5-75 \%$, CO reduced $13.9-55.8 \%$, HC reduced $30.3-45.7 \%$. $\mathrm{NO}_{\mathrm{x}}$ reduced $50 \%$.

2. Ethylene glycol ethyl ether palm oil monoester

The cylinder pressure analysis indicated that, the peak pressure reduced about $7 \%$ as well as the calculated heat release rate, while the ignition delay advanced $2.5 \mathrm{deg}$. CA. And engine brake thermal efficiency was improved for the fast combustion processes within the cylinder.

When diesel engine is fueled with this palm oil monoester, exhaust smoke reduced $36.5 \%$ to $60.0 \%$ when pure operation and $10 \%$ to $25 \%$ when the engine ran on the mixture of $25 \%$ blending with petrodiesel. Engine speed had a little effect on it. B100 made CO emission reduce $25 \%$ to $66 \%$, HC reduce $44.4 \%$ to $55.6 \%, \mathrm{NO}_{\mathrm{x}}$ reduce $17 \%$ to $32.2 \%$ according to the engine load and speed, respectively.

3. Ethylene Glycol n-Propyl Ether Palm Oil Monoester [45].

With an increase of EGPEPOM in the blends, the peak cylinder pressure decreased while the start of combustion advanced. Meanwhile, the BSFC and brake thermal efficiency increased because of the low LHV and high oxygen content.

Smoke reduction was not significant when B25 operating, while B100 fueled operation, smoke reduced by $50 \%$ approximately. CO reduced $33.2 \%$ for B25 and $66.6 \%$ for $\mathrm{B} 100$. HC were $11 \%$ for B25 and $27.1 \%$ for $\mathrm{B} 100 . \mathrm{NO}_{\mathrm{x}}$ were reduced by $15.8 \%$ to $23.7 \%$ for $\mathrm{B} 25$ and $\mathrm{B} 100$ operating conditions.

4. Propylene glycol methyl ether palm oil monoester [44].

For the tested engine working under partial load mode, smoke emissions generally can be lessened by more than $50 \%$ and up to $75.0 \%$. CO emissions can be reduced by $16.7 \%$ to $76.2 \%$. HC emissions can be diminished relatively by $12.5 \%$ to $67.7 \%$. $\mathrm{NO}_{x}$ emissions generally do not change.

\section{DGMECOM [46].}

Highest smoke reduction was about $60 \%$ and $80 \%$ at low load condition, about $40 \%$ and $45 \%$ at high load condition when b24 and b100 fuel applied respectively.

$\mathrm{HC}$ and $\mathrm{CO}$ changed irregularly, but were at the same level. $\mathrm{NO}_{\mathrm{x}}$ reduced and affected with engine speed and load. High speed and load might result in significant $1 / 3$ reduction in the test conditions.

The peak cylinder pressure decreased 1 or 2 bar, but combustion started earlier 2 or 3 deg. $\mathrm{CA}$, the peak heat release rate moved forward and decreased, as a result the engine brake thermal efficiency changed a little high, correspondingly to the fuel ratios and operating conditions.

6. TGMECOM [47].

The combustion of TGMECOM was quite like DGMECOM, ignition delay was shorter and heat release rate decreased. The engine brake thermal efficiency and BSFC increased a little.

Smoke reduction rate was as high as $54.6 \%$, $\mathrm{NO}_{\mathrm{x}}$ reduced from $16.6 \%$ to $40 \%$, CO reduced while HC increased all about $20 \%$ approximately.

The maximal reduction rate of emissions when using different biodiesel is summarized in Table 4 . New model biodiesels have more obvious effects than FAME on reducing smoke and HC on account of 
its higher $\mathrm{CN}$ and oxygen content. However new model biodiesels have a little influence in reducing $\mathrm{NO}_{x}$ and $\mathrm{CO}$ except EGEESOM and PGMEPOM. The different effects on engine emissions should be studied further.

Table 4. Maximal reduction rate of emissions when using pure biodiesels [44-47].

\begin{tabular}{ccccc}
\hline Fuel Type & Smoke & HC & CO & NO $_{\mathbf{x}}$ \\
\hline FAME & $47.4 \%$ & $36.4 \%$ & $62.5 \%$ & $24.2 \%$ \\
EGEESOM & $83.3 \%$ & $76.7 \%$ & $64.7 \%$ & Increase slightly \\
EGEEPOM & $60.0 \%$ & $66 \%$ & $55.6 \%$ & $32.2 \%$ \\
EGnPEPOM & $50 \%$ & $66.6 \%$ & $27.1 \%$ & $23.7 \%$ \\
PGMEPOM & $75 \%$ & $76.2 \%$ & $67.7 \%$ & changeless \\
DGMECOM & $80 \%$ & $33.3 \%$ & $33.3 \%$ & $33.3 \%$ \\
TGMECOM & $54.6 \%$ & Increase $20 \%$ & $20 \%$ & $40 \%$ \\
\hline
\end{tabular}

\section{Conclusions and Discussions}

\subsection{Ether Group Has Significant Effects on Fuel Properties}

Ether group increases oxygen content and cetane number of the new model biodiesels, which meets the research purpose changing the fuel properties of biodiesels.

From Table 1, the density of petrodiesel, FAME and the new model biodiesels increases normally from 860, 880 and 910 approximately. Oxygen content changes from $10 \%$ to $14 \%$. But their LHVs are generally in the same value, though lower than diesel. The higher density helps keep the engine power for most diesel engine fuel injection is valued in volume by compensating energy density. The shortage is their higher viscosity, which is more dispersing than its density and oxygen content, though there is no proof of bad effect on spray atomization, air fuel diffusion and finally its combustion.

\subsection{Ether Group Has Significant Effects on Engine Combustion and Emissions}

Fatty acid has an enough long chain, but FAME's cetane number is not so high for its unsaturated bonds. By introducing ether group, the $\mathrm{CN}$ of new model biodiesels increased to be 70 , a big improvement compared to FAME of 50, in a simple way. Engine combustion analysis indicates the following factors: higher cetane number shortens the ignition delay time, which increases the temperature of air fuel mixture within the scope of spray; shorter ignition delay wakens premixing combustion and results in lower $\mathrm{NO}_{\mathrm{x}}$ formation and emission; higher oxygen content decreases $\mathrm{PM}$ formation and emission; and both of higher $\mathrm{CN}$ and oxygen content together improve the biodiesel fuel combustion for the special chemical groups of ether and ester.

The developed new model biodiesels have higher potential to decrease smoke, $\mathrm{NO}_{\mathrm{x}}, \mathrm{HC}$ and CO than FAME. Most results indicated that FAME reduced smoke $30 \%$ to $50 \%$, but the new model biodiesel reduced engine smoke as high as $80 \%$. It also has significant reducing effects on $\mathrm{NO}_{\mathrm{x}}, \mathrm{HC}$ and $\mathrm{CO}$. Concerning that the test engine was a type of Euro 1, further studies should be carried out with engines meeting euro 6 to make sure its potentials.

\subsection{One Methyl Ether Group Is Important}

The engine test results indicate that one methyl ether group is important to boost the biodiesel combustion properties. While ethyl ether, propyl ether and even poly ethylene glycol methyl ether do not show better performance than ethylene glycol methyl ether. This helps keep the price of new model biodiesels low, too.

\subsection{Biodiesel Combustion Chemical Kinetics Should Be Studied}

From the point of cetane number, fatty acid, FAME and the new model biodiesel, they have the same types of alkylchain, the difference is the transesterified ester or ethylene glycol methyl ether ester 
group. Their $\mathrm{CN}$ improved much, so the effect on combustion should be investigated, as well as the mechanism of its effects on exhaust emissions.

Author Contributions: S.L. and H.G. conceived and designed the research topic by screening some of alcohols, ethylene glycol monomethyl ether was proposed. H.G. also designed the laboratory procedures for the new types of biodiesels transesterification processes. S.L. supervised the engine tests and data analyses of fuel properties and engien performances. W.C. Wrote the text of the manuscript first and then the manuscript was revised and submitted by Z.Z. Z.Z., S.J. and T.R. took part in the data comparsion with all the references.

Funding: This research was funded by NSFC, grant number 50976125 . The APC was funded by Key innovation research and development program of Shaanxi Province, grant number 2018ZDCXL-GY-05-06.

Acknowledgments: The authors appreciate to the financial support of NSFC 50976125 and Key innovation research and development program of Shaanxi Province 2018ZDCXL-GY-05-06. And thanks to our research group members for their excellent works and contributions to this review.

Conflicts of Interest: The authors declare no conflicts of interest.

\title{
Abbreviations
}

AT
BT
CA
CO
CO
CN
CP
OS
DOE
DU
EGME
FAME
EGMEROM
EGMESOM
EGMEPOM (Peanut)
EGMEPOM (Palm)
EGMECOM
EGEESOM
EGEEPOM
EGnPEPOM
PGMEPOM
DGMECOM
TGMECOM
FTIR
HC
HCI
LHV
K
Na
NO
OC
PM

\author{
Autoignition Temperature $/{ }^{\circ} \mathrm{C}$ \\ Boiling Temperature $/{ }^{\circ} \mathrm{C}$ \\ Crank angle $/\left(^{\circ}\right)$ \\ Carbon monoxide \\ Carbon dioxide \\ Cetane number \\ Cold Filter Plugging Point $/{ }^{\circ} \mathrm{C}$ \\ Oxidative Stability \\ Department of Energy, US \\ Degree of unsaturation
}

Ethylene Glycol Monoethyl Ether

Fatty acid methyl ester

Ethylene Glycol Methyl Ether Rapeseed Oil Monoester

Ethylene Glycol Methyl Ether Soyate Oil Monoester

Ethylene Glycol Methyl Ether Peanut Oil Monoester

Ethylene Glycol Methyl Ether Palm Oil Monoester

Ethylene Glycol Methyl Ether Cottonseed Oil Monoester

Ethylene glycol ethyl ether Soyate oil monoester

Ethylene glycol ethyl ether palm oil monoester

Ethylene Glycol n-Propyl Ether Palm Oil Monoester

Propylene glycol methyl ether palm oil monoester

Di-ethylene Glycol Methyl Ether Cottonseed Oil Monoester

Tri-ethylene Glycol Methyl Ether Cottonseed Oil Monoester

Fourier Transform Infrared Spectroscopy

Hydrocarbons

Hydrochloric acid

Lower Heating Value/ $(\mathrm{KJ} / \mathrm{Kg})$

Kalium; potassium

Sodium

Nitrogen oxides

Oxygen Content/\%

Particulate matters 


\section{Appendix A}

Table A1. FAME compositions and fuel properties [18-23,29].

\begin{tabular}{|c|c|c|c|c|c|c|c|c|c|c|c|}
\hline $\begin{array}{c}\text { Fatty Acids } \\
\text { wt. } \%\end{array}$ & Rapseed & Soybean & $\begin{array}{c}\text { Vernicia } \\
\text { Fordii }\end{array}$ & $\begin{array}{c}\text { Cornus } \\
\text { Wilsoniana }\end{array}$ & $\begin{array}{c}\text { Idesia } \\
\text { Polycarpa }\end{array}$ & $\begin{array}{c}\text { Zanthoxylum } \\
\text { Bungeanum }\end{array}$ & $\begin{array}{l}\text { Xanthoceras } \\
\text { Sorbifolia }\end{array}$ & $\begin{array}{c}\text { Armeniaca } \\
\text { Sibirica }\end{array}$ & $\begin{array}{c}\text { Jatropha } \\
\text { Curcas }\end{array}$ & $\begin{array}{c}\text { Pistacia } \\
\text { Chinensis }\end{array}$ & $\begin{array}{c}\text { Elaeis } \\
\text { Guineensis }\end{array}$ \\
\hline C14:0 & 0.07 & 0.05 & 0.03 & 1.00 & & & & & & & \\
\hline C16:0 & 3.49 & 10.58 & 3.56 & 16.53 & 15.50 & 20.14 & 5.27 & 3.79 & 19.75 & 23.14 & 44.80 \\
\hline C16:1 & 0.00 & 0.00 & 0.97 & 6.65 & 0.30 & 0.67 & 0.99 & 0.30 & & & \\
\hline C18:0 & 0.85 & 4.76 & 2.62 & 1.77 & 1.39 & 0.15 & 1.92 & 1.01 & 4.63 & 1.18 & 3.80 \\
\hline C18:1 & 64.40 & 22.52 & 10.57 & 30.50 & 9.53 & 29.72 & 31.17 & 65.23 & 46.83 & 44.35 & 39.90 \\
\hline C18:2 & 22.30 & 52.34 & 14.64 & 48.50 & 64.81 & 29.62 & 44.47 & 28.92 & 28.50 & 28.51 & 9.28 \\
\hline C18:3 & 8.23 & 8.19 & 59.20 & 1.60 & 2.08 & 17.91 & 6.46 & 0.14 & 0.01 & 0.84 & 0.22 \\
\hline C20:0 & 0.10 & 0.20 & 0.09 & 0.17 & 0.10 & 0.35 & & & & & \\
\hline C20:1 & 0.90 & 0.04 & 0.48 & 0.12 & & & & & & & \\
\hline C20:3 & 7.27 & & & & & & & & & & \\
\hline Others & 0.73 & 1.61 & 8.51 & 0.05 & 1.53 & 3.24 & 0.89 & 0.03 & & & \\
\hline $\mathrm{CP} /{ }^{\circ} \mathrm{C}$ & -4 & -0.5 & -11.0 & 0.0 & -5.0 & -6.0 & -8.0 & -14.0 & 0 & -3.0 & 12.0 \\
\hline $\begin{array}{c}\mathrm{OS} / \mathrm{h} @ 110 \\
{ }^{\circ} \mathrm{C}\end{array}$ & 2.0 & 1.3 & 0.4 & 0.6 & 0.7 & 1.2 & 1.7 & 2.7 & 3.3 & 4.2 & 7.7 \\
\hline $\mathrm{CN}$ & 52.9 & 50.9 & 37 & 49 & 45 & 46 & 47.6 & 48.8 & 51 & 51.3 & 62.0 \\
\hline
\end{tabular}




\section{References}

1. 2017 China Petroleum Market Analysis. Available online: https://wenku.baidu.com/view/ 3946d7dc64ce0508763231126edb6f1aff0071fa.html (accessed on 26 January 2018).

2. Cárdenas, M.D.; Armas, O.; Mata, C.; Soto, F. Performance and pollutant emissions from transient operation of a common rail diesel engine fueled with different biodiesel fuels. Fuel 2016, 185, 743-762. [CrossRef]

3. Liu, S. Internal Combustion Engine Fundamentals, 4th ed.; China Machine Press: Beijing, China, 2017; ISBN 978-7-111-56286-3.

4. Ministry of Ecology and Environment of the People's Republic of China. China Vehicle Environmental Management Annual Report 2018. Available online: http://dqhj.mep.gov.cn/jdchjgl/zhgldt/201806/ P020180604354753261746.pdf (accessed on 1 June 2018).

5. Production Statistics. Available online: http:/ /biodiesel.org/ (accessed on 6 June 2018).

6. EU to Adjust Biodiesel Policy. Available online: http://www.china-nengyuan.com/news/126188.html (accessed on 1 July 2018).

7. Analysis of China's Biodiesel Market in 2018. Available online: http://www.chyxx.com/industry/201805/ 636866.html (accessed on 18 July 2018).

8. The State Council Circular on the Issuance of the 12th Five-year Plan for Energy Development. Available online: http:/ / www.nea.gov.cn/2013-01/28/C_132132808.htm (accessed on 7 July 2018).

9. The National Development and Reform Commission Circular on the Issuance of the 13th Five-year Plan for Energy Development. Available online: http:/ / www.ndrc.gov.cn/zcfb/zcfbtz/201612/t20161216_830264. html (accessed on 10 July 2018).

10. The National Energy Administration Circular on the Issuance of Biodiesel Industry Development Policy. Available online: http:/ /zfxxgk.nea.gov.cn/auto83/201501/t20150123_1882.htm (accessed on 10 July 2018).

11. Lapuerta, M.; Armas, O.; Rodriguezfernandez, J. Effect of biodiesel fuels on diesel engine emissions. Prog. Energy Combust Sci. 2008, 34, 198-223. [CrossRef]

12. Tanzer, E.; Murat, K.Y. Influence of blending ratio on the physicochemical properties of safflower oil methyl ester-safflower oil, safflower oil methyl ester-diesel and safflower oil-diesel. Renew. Energy 2016, 95, 233-247. [CrossRef]

13. Gerhard, K. "Designer" Biodiesel: Optimizing Fatty Ester Composition to Improve Fuel Properties. Energy Fuel 2008, 22, 1358-1364. [CrossRef]

14. Anantharaman, G.; Krishnamurthy, S.; Ramalingam, V. A review on combustion, performance, and emission characteristics of fuels derived from oil seed crops (biodiesels). Aust. J. Crop Sci. 2013, 7, 1350-1354.

15. Pankin, K.E.; Ivanova, Y.V.; Kuz'Mina, R.I.; Shtykov, S.N. Comparison of the physicochemical characteristics of biofuels and petroleum fuels. Chem. Technol. Fuels Oils 2011, 47, 7-11. [CrossRef]

16. Han, B.; Zhang, W.; Yin, F.; Liu, S.; Zhao, X. Advantages, Problems and Countermeasure on the Development of Biodiesel Industry in Yunnan Province. Farm Prod. Process. 2016, 2016, 48-52. [CrossRef]

17. Tyson, S.; McCormick, R. Biodiesel Handling and Use Guidelines, 3rd ed.; US Department of Energy. Available online: http:/ / www.biodiesel.org/reports/20060909_gen-317.pdf (accessed on 21 June 2018).

18. McCormick, R.L.; Williams, A.; Ireland, J.; Brimhall, M.; Hayes, R.R. Effects of Biodiesel Blends on Vehicle Emissions. National Renewable Energy Laboratory, U.S. Department of Energy. Available online: https: / / www.nrel.gov / docs / fy07osti / 40554.pdf (accessed on 1 June 2018).

19. European Parliament Directive 2009/30/EC. Available online: https://www.mendeley.com/researchpapers / european-parliament-directive-200930ec/ (accessed on 1 July 2018).

20. Xin, Y. Developing Status of Biodiesel in Germany and Europe. China Oils Fats 2008, 2008, 1-6.

21. Wang, L.; Yu, H.; He, X. Influence of fatty acid composition of woody biodiesel plants on the fuel properties. J. Fuel Chem. Technol. 2012, 40, 397-404. [CrossRef]

22. Canakci, M.; Sanli, H. Biodiesel Production from Various Feedstocks and their effects on the fuel properties. J. Ind. Microbiol. Biotechnol. 2008, 35, 431-441. [CrossRef] [PubMed]

23. Serrano, M.; Bouaid, A.; Martínez, M.; Aracil, J. Oxidation stability of biodiesel from different feedstocks: Influence of commercial additives and purification step. Fuel 2013, 113, 50-58. [CrossRef]

24. Karmakar, A.; Karmakar, S.; Mukherjee, S. Properties of various plants and animals feedstocks for biodiesel production. Bioresource Technol. 2010, 101, 7201-7210. [CrossRef] [PubMed] 
25. Islam, M.A.; Magnusson, M.; Brown, R.J.; Ayoko, G.; Nabi, M.; Heimann, K. Microalgal Species Selection for Biodiesel Production Based on Fuel Properties Derived from Fatty Acid Profiles. Energies 2013, 6, 5676-5702. [CrossRef]

26. Ramos, M.J.; Fernández, C.M.; Casas, A.; Rodríguez, L.; Pérez, Á. Influence of fatty acid composition of raw materials on biodiesel properties. Bioresour. Technol. 2008, 100, 261-268. [CrossRef] [PubMed]

27. Knothe, G.; Matheaus, A.C.; Ryan, T.W. Cetane numbers of branched and straight chain fatty esters determined in an ignition tester. Fuel 2003, 82, 971-975. [CrossRef]

28. Zhu, Z.; Guo, H.; Zhou, A.; Li, D.; Liu, S. One Way to reduce the NOx emission of biodiesel: The increase of cetane number. Int. J. Green Energy 2016, 13, 957-962. [CrossRef]

29. Chen, L.; Wang, Z.; Li, M. Effects of CN Improver DTBP on biodiesel combustion and emissions. In Proceeding of the China Society of ICE, Shanghai, China, 8-11 August 2011.

30. Rakopoulos, D.C.; Rakopoulos, C.D.; Giakoumis, E.G.; Dimaratos, A.M.; Kyritsis, D.C. Effects of butanol-diesel fuel blends on the performance and emissions of a high-speed DI diesel engine. Energy Convers. Manag. 2010, 51, 1989-1997. [CrossRef]

31. Sebastian, J.; Nagarajan, G. Experimental Study on Influence of Fuel Oxygen Content on Combustion and Emission Characteristics of a Direct Injection CI Engine; SAE 2010-01-1969; SAE: Warrendale, PA, USA, 2010.

32. Guo, H.; Liu, S.; Zhou, L. Study on Ethylene Glycol Monomethyl Ether Peanut Oil Monoester as a Novel Biodiesel; SAE 2008-01-1575; SAE: Warrendale, PA, USA, 2008.

33. Jiang, D.Y.; Guo, H.J.; Liu, S.H. Research on a new rapeseed oil monoester as a clean fuel for diesel engine. Fuel 2006, 51, 859-861.

34. Jiang, D.; Wang, X.; Liu, S.; Guo, H. Rapeseed Oil Monoester of Ethylene Glycol Monomethyl Ether as a New Biodiesel. Biomed. Res. Int. 2011, 2011, 293161. [CrossRef]

35. Mani, N.; Edwin, A.F.; David, W.N. Oxygenates for Advanced Petroleum Based Diesel Fuels: Part 1. Screening and Selection Methodology for the Oxygenates; SAE 2001-01-3631; SAE: Warrendale, PA, USA, 2001.

36. Guo, H.; Liu, S.; He, J. Performances and Emissions of New Glycol Ether Blends in Diesel Fuel used as Oxygenated Fuel for Diesel Engines. Am. Soc. Civ. Eng. 2015, 142. [CrossRef]

37. Rakopoulos, C.D.; Giakoumis, E.G.; Dimaratos, A.M. Investigation of the combustion of neat cottonseed oil or its neat bio-diesel in a HSDI diesel engine by experimental heat release and statistical analyses. Fuel 2010, 89, 3814-3826. [CrossRef]

38. Guo, H.; Xun, Q.; Liu, S. Investigation of Ethylene Glycol Monomethyl Ether Soyate as a Biofuel; SAE 2015-01-0955; SAE: Warrendale, PA, USA, 2015.

39. Zhang, H.; Li, Q.; Li, H.; Ma, Z. Study of the ethylene glycol monoether of soyate for biodiesel production. Renew. Energy Resour. 2010, 28, 43-47. [CrossRef]

40. Chen, X.; Guo, H.; Zhang, L. Research on Ethylene Glycol Monoethyl Ether Palm Oil Monoester as a Novel Biodiesel-Like Fuel and Its Effecton Diesel Engine Performance; SAE 2014-01-1469; SAE: Warrendale, PA, USA, 2014.

41. Jiang, D.; Bai, Y.; Guo, H. Exhaust emissions and combustion performances of ethylene glycol monomethyl ether palm oil monoester as a novel biodiesel. Afr. J. Biotechnol. 2011, 10, 16300-16313. [CrossRef]

42. Guo, H.; Wang, R.; Su, J. Study of Ether Group Effects on Physicochemical Properties of Cottonseed Oil Ether Monoesters as Novel Biodiesels; SAE 2013-01-2601; SAE: Warrendale, PA, USA, 2013.

43. Li, Y.; Guo, H.; Zhu, Z.; Feng, Y.; Liu, S. Ethylene glycol monomethyl ether cottonseed oil monoester: Properties evaluation as biofuel. Int. J. Green Energy 2012, 9, 376-387. [CrossRef]

44. Ma, J.; Wang, X.; Guo, H. Research on the new kinds of oxygenated diesel fuels. Energy Eng. 2010, 2010, 28-31. [CrossRef]

45. Gao, G.; Feng, Y.; Guo, H.; Liu, S. Synthesis, Structure Characterization, and Engine Performance Test of Ethylene Glycol n-Propyl Ether Palm Oil Monoester as Biodiesel. Energy Fuel 2011, 25, 4686-4692. [CrossRef]

46. Wang, W.; Wang, X.; Guo, H.; Jiang, D.; Zhang, J. Research on the synthesis and performances of a new biodiesel, propylene glycol methyl ether palm oil monoester. In Proceedings of the 2011 International Conference on Electric Information and Control Engineering, Wuhan, China, 15-17 April 2011.

47. Li, Z.; Guo, H.; Su, J.; Wang, R. Synthesis of Diethylene Glycol Monomethyl Ether Cottonseed Oil as a Novel Biodiesel. China Contemp. Chem. Ind. 2012, 41, 116-119. [CrossRef]

48. Zhou, A.; Guo, H.; Chen, X.; Wang, H.; Liu, S. Preparation, Structure Analysis, and Engine Performance Test of Triethylene Glycol Monomethyl Ether Cottonseed Oil Monoester as Biodiesel; SAE 2013-6-0096; SAE: Warrendale, PA, USA, 2013. 
49. Lou, S.; Jia, L.; Guo, X.; Wu, P.; Gao, L.; Wang, J. Preparation of diethylene glycol monomethyl ether monolaurate catalyzed by active carbon supported KF/CaO. Springerplus 2015, 4, 686. [CrossRef] [PubMed]

50. Guo, H.; Liu, S. Study of Ether Species Effects on Physicochemical Properties of Palm Oil Ether Monoesters as Novel Biodiesels. Int. J. Chem. Mol. Nucl. Mater. Metall. Eng. 2013, 7, 11. [CrossRef]

(c) 2018 by the authors. Licensee MDPI, Basel, Switzerland. This article is an open access article distributed under the terms and conditions of the Creative Commons Attribution (CC BY) license (http://creativecommons.org/licenses/by/4.0/). 